Egypt.J. Aquat. Bion. \& Fish., Vol.5, No.3:151-163 (2001) ISSN 1110-6131

\title{
EFFECT OF DIETARY PROTEIN SOURCE ON GROWTH OF OREOCHROMIS NILOTICUS
}

\author{
Ragab Abd El-Regal Mohammed
}

National Institute of Oceanography and Fisheries, Fish Rearing Lab., Al-

Kanater AL-Khyria, Egypt

\section{ABSTRACT}

$O$ reochromis niloticus fingerlings with initial body weight and length ranging from 20 to $39.5 \mathrm{~g}$ and from 10 to $13.5 \mathrm{~cm}$., respectively.were reared in two cement ponds at a density of 4 fish $/ \mathrm{m}^{2}$. The two cement ponds were divided into five equal divisions (partitions) by nets. Fishes in each partition were fed on one of the experimental diets at $3 \%$ of body weight 6 times a week for a period of 130 days.

This research was carried out at Al-Kanater AL-Khayria Fish Research Station to study the effect of dietary protein sources on growth of $O$. niloticus. Growth rate, average daily gain, specific growth rate and feed conversion ratio were determined. The results indicated that the highest growth rate (0.86), highest specific growth rate $(0.96)$, maximum weight gain percentage $(250.6 \%)$ and the lowest feed conversion ratio (2.37) were obtained for fish fed the formulated diet containing $25 \%$ protein, whereas the opposite was found for fish fed wheat bran alone. Results also showed that animal protein diet was better than plant protein diet for tilapia feeding. From the economical point of view, the results indicated that the balanced diet containing $20 \%$ protein was the most suitable diet for fish feeding in the cement ponds.

\section{INTRODUCTION}

Fish represent one of the most important sources of animal protein. Tilapia are the third largest group of farmed finfish species after carp and salomonids (FAO, 1997). EL-Sayea (1999) mentioneu' that tilapia have gained a great culture potential in many tropical andi subtropical regions of the world. Among tilapia species, Oreochromis niloticus represents the most suitable for fish culturing in Egypt (Bayoumi, 1987). 
Wannigame et al (1985) found that Oreochromis niloticus resed from $2 ?-30 \mathrm{~g}$ to $77.107 \mathrm{~g}$ in cages, held in freshwater and fed diets containing $19,20,25$ and $29 \%$ protein, the best growth rate was found for $20 \%$ promein level. Siddiqui et al. (1988) obtained maximum growth wh a $30 \%$ prowin diet (vs 20,40 and $50 \%$ protein) of 0 . niloficus reared from about 40 to $111.3-163 \mathrm{~g}$ in concrete tanks. De-Silva and Gumasekera (1989) demonstrated that the mosi economical dietary protein requirement for young tilapia was $28^{\circ} \mathrm{o}$. while maximum growth ate was achieved at about $34 \%$ protein Sweilum (1995) reported that food conversion of Tilapia nilotica under polyculure system was decreased with increasing dietary protein level. In culluring fish in captivity, nothing is more important than sound nutrition and adcquate feeding. If the feed is not consumed by the fish or if the fish are unable to utilize their feed. then will be no growth. However, the feeding programme differed from onc farm to another. Some fish farmers feed their stocks on wheat bran as a common and available diet, while others mix wheat bran with one of animal or plant protein source. In addition. the majority of fish farm. depend upon the formulated dry fish feed containing different protein levels in order to increase the production of the farm. Therefore, the present research ains to study the effects of dietary protein sources on growth rate of $O$. niloticus and fish performance alongside the economical evaluation for the investigated diets.

\section{MATERIAL AND METHODS}

This study was carried out at Al-Kanater Fish Research Station, Al-Kanater Al-Khayria. Qalubia, Egypt.

\section{Experimental ponds:}

Two cement ponds were divided into 5 equal division each of an area about $20 \mathrm{~m}^{2}$, using fine meshed nets made of naylon. Bottom of these ponds was covered with $10 \mathrm{~cm}$ of sandy clay loam soil. Ponds were supplied by fresh water from River Nile throughout Darawa canal. About thirty percent of the water volume was drained and replenished daily Throughout the experimental duration, water depth was maintained at $100-120 \mathrm{~cm}$. Fingerlings of $O$. niloticus with initial weight ranging from 20 to $39.5 \mathrm{~g}$ and initial length ranging between 10 and $13.5 \mathrm{~cm}$ were randomly distributed at a rate of $4 \mathrm{fish} \mathrm{m}^{2}$ into the experinental groups. Each partition (group) was fed on one of the experimental diets which including wheat bran alone to feed mishes in 
and $13.5 \mathrm{~cm}$ were randomly distributed at a rate of $4 \mathrm{fish} / \mathrm{m}^{2}$ into the experimental groups. Each partition (group) was fed on one of the experimental diets which including wheat bran alone to feed fishes in the partition No. 1, wheat bran and soybean for the partition No.2, wheat bran mixed with fish meal for the partition No.3, two balanced diets containing 20 and $25 \%$ protein for feeding fishes in the partitions No. 4 and 5 respectively. The ingredients were mixed and formulated as finely pellet diets. Crude protein, . lipid and. fiber were calculated according to NRC (1993). Constituents and a proximaie chemical composition of the experimental diets are given in Table (1). Feeds were offered to fish once daily at a rate of $3 \%$ of body weight 6 times a week for 130 days (from July to November, 2000). Random samples of the reared fish (about 30\%) from each experimental groups were monthly weighed to the nearest $0.1 \mathrm{~g}$ and measured to the nearest 0.1 $\mathrm{cm}$. Weight of the supplementary feeds was readjusted according to the increase in fish body weight. Feed intake, body weight were recorded every month and the feed conversion ratio were calculated. Feed consumed, feed costs and costs of producing one $\mathrm{kg}$ fish of each group were calculated using the ingredient cost in effect at that time.

Fish performance was calculated from the following equations: Average daily gain $(A D G)=($ Final weight - initial weight $) /$ period in days

Specific growth rate (SGR) $=100$ [(In final weight - In initial weight)/period in days]

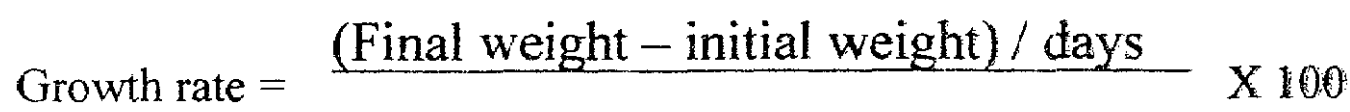

$($ Final weight + initial weight $) / 2$

According to Winberg (1960).

Feed conversion ratio $(\mathrm{FCR})=($ Feed intake $(\mathrm{g}) /$ weight gain $(\mathrm{g}))$

Soil chemical properties were determined according to Jackson (1967). Water temperature was recorded daily, while water quality parameters including: dissolved oxygen at 9.0 a.m., water $\mathrm{pH}$, electrical conductivity, water alkalinity and water hardness were determined according to the standard methods of American Public Health Association, APHA (1993).

Statistical analysis of variance (ANOVA) was carried out according to Sendecor and Cochran (1980). The significance of differences among treatments was determined using least significant 


\section{RESULTS AND DISCUSSION}

Water quality of the experimental ponds is recorded in Table (2). The results indicated that water temperature ranged from 27.5 to $28.5^{\circ} \mathrm{C}$ with average of $28 \pm 1^{\circ} \mathrm{C}$. Water $\mathrm{pH}$ was slightly alkaline, where it ranged from 8.13 to 8.17 , the electrical conductivity of water ponds varied between 315 and $350 \mathrm{mhos} / \mathrm{cm}$, water alkalinity varied in a narrow range, between 180 and $185 \mathrm{mg} \mathrm{CaCO}_{3} / \mathrm{L}$, while total hardness varied from 162.5 to $175 \mathrm{mg} \mathrm{CaCO} / \mathrm{L}$. Properties of soil monds were slightly alkaline, its organic matter percentage was $1.6 \%$ and the electrical conductivity was $450 \mathrm{mhos} / \mathrm{cm}$ at $25^{\circ} \mathrm{C}$. The above mentioned ranges are near to the suitable conditions for culturing $O$. niloticus. Moreover, the results confirming that water quality and soil properties were within the suitable range for fish farming as mentioned by Hepher and Pruginin (1981).

With respect to growth rate of $O$. niloticus, results in Table (3) and Figures. (1, $2 \& 3$ ) showed that, firstly, there is no noticable differences between initial fish body weight of all groups (Fig. 1) but the difference between final weights was significant due to the different diets (Fig. 2). With respect to monthly increament in body weights, results showed that fish weight gradually increased throughout period of the study and the growth rate of $O$. niloticus increased with the increase in protein percent in the added diet. Moreover, growth rate of the reared fishes also differed according to the variation in protein source. Fish fed on the balanced diets containing 20 or $25 \%$ protein partitions No. 4 and 5 showed the highest growth rate $(0.82$ and 0.86 , respectively), while the lowest growth rate was attained with a diet containing one source of protein either plant or animal protein.

Values of growth rate for the different diets ranged between 0.63 and 0.86 . These results agree with results of Al-Ogaily et al. (1996) who respected that growth rate of $O$. niloticus differed according to protein percent in the diet.

Growth performance: The present results (Table 4) showed that the average of final body weight differed from one division to another according to the type of the diets. The highest final body weight $(93.86 \mathrm{~g})$ was recorded in the partition No. 5 where fishes fed on the balanced diet containing $25 \%$ protein followed by those fed on the diet containing $20 \%$ protein (partition No. 4), whereas the lowest final body weight $(68.98 \mathrm{~g})$ was found with fish fed on wheat bran 
weight $(93.86 \mathrm{~g})$ was recorded in the partition No. 5 where fishes fed on the balanced diet containing $25 \%$ protein followed by those fed on the diet containing $20 \%$ protein (partition No. 4), whereas the lowest final body weight $(68.98 \mathrm{~g})$ was found with fish fed on wheat bran alone (partition No. 1). The statistical analysis showed that there is no significant difference between final body weight of fishes in partitions No. 4 and 5 where fish fed balanced diets $(20 \& 25 \%)$, while the difference between fishes fed the two balanced diets and that containing one of protein source either soybean (group No. 2) or fish meal (group No. 3) was significant. On the other hand. results indicated that there is no significant difference between final fish weights which fed the diet containing wheat bran plus fish meal (partition No. 3) and that contained wheat bran plus soybean (partition No. 2), Table (4). These results agree with finding of Wang et al. (1985) and Kheir and Sweilum (1997) whom reported that growth of tilapia affected by protein percent in the feeding diet. Gunasekera $t$ al. (1995) mentioned that O. niloticus maintained on 10 and $17 \%$ protein levels showed lower growth rate compared to those of the higher protein levels.

Similar trend was achieved with final body length. The bighest body length $(17.4 \mathrm{~cm})$ was observed for fish fed the diet containing $25 \%$ protein (group No. 5) while the lowest length $(15.57 \mathrm{~cm}$ ) was found for fish fed wheat bran alone (group No. 1). With respect to gain in fish weight, results indicated that it ranged between $40.42 \mathrm{~g}$ and $67.09 \mathrm{~g}$ per fish after 130 days. The highest weight gain $(67.09 \mathrm{~g})$ was obtained for fish fed on the diet containing $25 \%$ protein, while the lowest value $(40.42 \mathrm{~g})$ was recorded for fish fed on wheat bran. At the same time, data indicated that weight gain percentage increased as the protein level increased in the diet. The maximum percentages in weight gain (250 and 226) were attained for fish fed on the two balanced diets containing 25 and $20 \%$, respectively, while the lowest percentage weight gain (141.5\%) was found in the first division where fish fed wheat bran alone (Table,4). This result agrees with those of Hassanen (1986) who pointed out that percentage in weight gain for $O$. niloticus increased with the increase in protein percent in the artificial diets. Concerning the changes in average daily gain (ADG) and specific growth rate (SGR) of $O$. niloticus as affected by the experimental diets, the present results indicated that the maxinum ADG $(0.52 \mathrm{~g} /$ fish/day $)$ and the highest SGR $(0.96 \% \mathrm{~g})$ was noticed in the partition No. 5 where fish fed the balanced diet (25\% protein). 
protein level in the diets, moreover, the animal protein source was hiter than plant protein for fish growth. The above results agree with previous results of many studies, Siddiqui et al (1988) found that the highest SGR for $O$. niloticus the highest protein percent in the experimental diets. Finsman-Kalio and Camacho (1987) reported that a diet containing $30 \%$ protein level produced better growth than 20 or $25 \%$ protein level when fed to O. niloticus. Gumasekera et al (1995) and Goda (1996) found that ADG of $O$. niloticus increased with the increase in protein level in the artificial diets. On the other hand, the results disagree with result of Clark et al. (1990) who mentioned that ADG and SGR were not significant for Florida red tilapia when fish leed diets containing $20 \%, 25 \%$ and $30 \%$ dietary protein level.

For indicating the variations in the condition factor of $O$. niloticus fed on the different diets, present results (Table, 4) showed that there is no noticable trend for their condition factor. This result may be due to that the variations in total body length was not significant. On the other hand, it can be noticed that condition factor of reared $O$. niloticus at the end of the study was higher than that of the initial in all groups.

Table (5) showed that the highest feed conversion ratio (FCR) (3.35) was attained for fish fed wheat bran while the lowest FCR (2.37) was found for fish fed the balanced diet containing $25 \%$ protein (partition No. 5). This result agrees with result of Sweilum (1995) who reported that FCR of $O$. niloticus under a polyculture system was decreased with increasing dietary protein levels. On the other hand, this result disagrees with the finding of Watanabe et al. (1990) who reported that FCR for fish fed on diet of $28 \%$ protein was lower than for those fed the $32 \%$ protein.

Economic evaluation:

Feed costs and cost of producing one $\mathrm{kg}$ of fish are shown in Table (5). Results showed that feed intake differed from one partition to another according to monthly increament in fish body weights. The highest feed intake (consumed) $\mathrm{kg} /$ partition was attained for fishes fed the balanced diet containing 25 protein while lowest quantity was cbserved in the first partition. So the lowest and the highest feed costs was attained in the first and the fifth partitions respectively. Due to the difference in price of the experimental diets, results showed that balanced diet containing $20 \%$ protein represent the most economical diet where cost of producing one $\mathrm{kg}$ fish was $1.97 \mathrm{~L}$.E. compared with the other diets. Results also showed that although the diet containing $25 \%$ protein gave the highest fish production and the lowest feed 
conversion ratio as shown in partition (No. 5), otherwise, cost of producing one $\mathrm{kg}$ fish was higher than that of diet containing $20 \%$ protein. Feasibility study found the relationship between the total cost of diets and production of each diet separately. From these results, it could be concluded that a diet formulated from local ingredients such as wheat bran, soybean and fish meal and containing $20 \%$ protein considere the economical diet for feeding $O$. niloticus in the fish farms.

\section{REFERENCES}

AL-Ogaily, S.M.; Al-Asgah, N.A. and Ali, A. (1996). Effect of feeding different grain sources on the growth performance and body composition of tilipia Oreochromis niloticus (L.). Aquacult., Res., 27 (7): 523-529.

APHA (American Public Health Association) (1993). Standard Methods for the Examination of the Water and Waste-water Including Bottom Sediments and Sludges. APHA, Washington, U.S.A.

Bayoumi, A.R. (1987). Development of fish farming in Egypt. Cage culture. Institute of Oceanog. and Fish, Cairo, Egypt and IDRC, Canada Rep., 5 (phase 11) pp. 63.

Clark, A.E.; Watanab, O.; Olla, B. L. and Wicklund, R.L. (1990). Growth, feed conversion and protein utilization of Florida red tilapia isocaloric diets with different protein levels in seawater pools. Aquacult., 88: 75 .

De-Silva, S.S. and Gunasekera, R.M. (1989). Effects of dietary protein level and amount of plant ingredient (Phaseolus aureaus) incorporated into the diets on composition, growth performance and carcaes composition in Oreochromis niloticus (L.) dry. Aquacult., 80: 121.

El-Sayed, A. F.M. (1999). Alternative dietary protein sources for farmed tilapia. Oreochromis spp. Aquacult., 179: 149-168.

FAO (1997). Aquaculture Production Statistics 1986-1995, FAO Fish. Circ. No. 815, Rev. 9. Rome, Italy. pp. 179. 
Fineman-Kalio, A.S. and Camacho A.S. (1987). The effect of supplemental feeds containing different protein: energy ratios on the growth and survival of Oreochromis niloticus (L.) in brakish water ponds. Aquaculture Fish Manage, 18: 139.

uoda A.M.A. (1996). Types of nutrition for freshwater fish. Ph.D. Thesis Fac. of Agric. Cairo Univ. Giza, Egypt.

Gunasekera, R.M.; Shim, K.F. and Lam, T.J. (1995). Effect of dietary protein level and puberty, oocyte growth and egg chemical composition in the tilapia, Oreochromis niloticus (L.). Aquacult., 134 (1-2): 169-183.

Hassanen, G.D.I. (1986). Studies on some appropriate ratio for reared fishes in Egyptian Fish Farms. Ph.D. Thesis Fac. Of Agric. Monofya Univ. 197.

Hepher, B. and Pruginin Y. (1981) Commercial Fish Farming. Fish and Aquaculture Research Station Dor Isrel, John Wiely and Sons Inc. New York. Toronto.

Jackson M.L. (1967). Soil Chemical Analysis. Constable and Co. Ltd. London.

Kheir M.T and Sweilum M.A. (1997). Effect of different dietary protein level on the growth, survival rates and body composition of fry Oreochromis niloticus. Bull. Fac. Sci. Zagazig Univ., Zagazig, 19(1): 274-286.

NRC, (1993). Nutrient Requirements of Fish-National Research Council. Washington, DC.

Sendecor, G.W. and Cochran, W.G. (1980). "Statistical Methods" $7^{\text {th }}$ Ed. Iowa State Univ. Press. Ames. Iowa U.S.A.

Siddiqui, A.Q.; Howlader, S.M. and Adam, A. (1988). Effect of dietary protein levels on growth, feed conversion and protein utilization in fry and young Nile tilapia, Oreochromis niloticus Aquacult., 70: 63-73. 
Effect of dietary protein source on growth of Oreochromis 159 niloticus

Sweilum, M.A. (1995). Studies on rearing of some available species of carp and tilapia in ponds. Ph.D. Thesis Fac. of Sci. Zagazig Univ. Zagazig, Egypt.

Wang, K.W.; Takeuchi, T. and Watanabe, T. (1985). Efect of dietary protein level on growth of Tilapia milotica. Bull. Jap. Soc. Sci. Fish., 51: 133-140.

Wannigama, N.D.; Weerakoon, D.E.M. and Muthukumarana. G. (1985). Cage culture of S. niloticus is Sri-Lanka: Erfect of stocking density and dietary crude protein level on growth. Methodological Approaches to Research and Development. IRDC, Ottawa, Ont, pp. 113-117. (Cited from Goda, 1996).

Watanabe, W.Q.; French, K.F.; Erust, D.H.; Olla, B.I. and Wicklund. R.I. (1989). Salinity during early development influerices survival and growth of Florida red tilapia in brackish and seawater. J. World Aquacult., Soc., 20(3): 134.

Winberg, G.B. (1960). Rate of metabolism and food requirements of fishes. Fish Res. Bd. Canada, 194-202. 
Table (1): Constituents, chemical composition and price of the experimental diets $/ 100 \mathrm{~g}$.

\begin{tabular}{|l|l|l|l|l|l|}
\hline \multicolumn{2}{|c|}{ Ingredients } & \multicolumn{5}{|c|}{ Diets } \\
\cline { 2 - 7 } & \multicolumn{1}{|c|}{$\mathbf{1}$} & \multicolumn{1}{|c|}{$\mathbf{2}$} & \multicolumn{1}{|c|}{$\mathbf{3}$} & \multicolumn{1}{|c|}{$\mathbf{5}$} \\
\hline Wheat bran (g) & 97.5 & 73.0 & 80.5 & 73.0 & 59.5 \\
Soybeart (g) & 0.0 & 24.5 & 0.0 & 20.0 & 30.0 \\
Fish meal (g) & 0.0 & 0.0 & 17.0 & 4.5 & 8.0 \\
Cotton sred oil (g) & 2.0 & 2.0 & 2.0 & 2.0 & 2.0 \\
Vitamins (g) & 0.5 & 0.5 & 0.5 & 0.5 & 0.5 \\
\hline Calculated crude protein & 11.70 & 19.54 & 19.95 & 20.28 & 25.18 \\
Caliculated crude lipid & 2.78 & 2.78 & 4.24 & 3.17 & 3.47 \\
Caiculated crude fiber & 0.20 & 1.94 & 0.28 & 1.64 & 2.36 \\
Metabolized energy (K cal/kg) & 2029 & 2109 & 2185 & 2136 & 2201 \\
Protein/energy ratio & 57.66 & 92.65 & 91.30 & 94.94 & 114.4 \\
Price of kg diet (L.E.) & 0.623 & 0.745 & 0.92 & 0.801 & 0.913 \\
\hline
\end{tabular}

Each gam vitamin contains: Vit. A $3000 \mathrm{IU}$; Vit. $B_{1} 2.5 \mathrm{mg}$; Vit. $B_{2} 2.5 \mathrm{mg}$; Vit. $B_{6}$ $0.75 \mathrm{me} ;$ Vit. $B_{12} 2.5 \mathrm{mg}$; Vit. D $300 \mathrm{IU}$; Vit. E $75 \mathrm{mg}$; Folvic acid 0.5mg; Cinamide $25 \mathrm{mg}$ and Carbon $40 \mathrm{mg}$.

Prices of one kg food ingredients (L.E.): wheat bran; 0.5, Soybean; 1.0, Fish meal; 2.25 , Cotton seed oil; 3.0, Vitamines; 15.0 .

Table (2): Some water characteristics of the experimental ponds.

\begin{tabular}{|c|c|c|c|c|c|}
\hline \multirow{2}{*}{ Water Character } & \multicolumn{5}{|c|}{ Partitions } \\
\hline & 1 & 2 & 3 & 4 & 5 \\
\hline Water temperature $\left({ }^{\circ} \mathrm{C}\right)$ & 28.0 & 28.5 & 28.0 & 27.5 & 28.0 \\
\hline Dissolved oxygen (mg/L) & 7.5 & 7.3 & 7.2 & 7.0 & 7.5 \\
\hline Water $\mathrm{pH}$ & 8.16 & 8.14 & 8.13 & 8.17 & 8.13 \\
\hline Electrical conductivity $(\mu \mathrm{mhos} / \mathrm{cm})$ & 350 & 320 & 325 & 315 & 320 \\
\hline Ph. Ph. alkalinity (mg CaCO$/ 2$ ) & 15.0 & 15.0 & 15.0 & 15.0 & 15.0 \\
\hline tal alkalinity (mg $\mathrm{CaCO}_{3} / \mathrm{L}$ ) & 185.0 & 182.5 & 182.5 & 180.0 & 185.0 \\
\hline Thal hardness ( $\mathrm{mg} \mathrm{CaCO}_{3} / \mathrm{L}$ ) & 170.0 & 170.0 & 167.5 & 162.5 & 175.0 \\
\hline
\end{tabular}


Table (3): Monthly body weight and growth rate of Oreochromis niloticus fed on different diets.

\begin{tabular}{|l|c|c|c|c|c|}
\hline \multirow{2}{*}{ Average Weight } & \multicolumn{5}{|c|}{ Partition } \\
\cline { 2 - 6 } & $\mathbf{1}$ & $\mathbf{2}$ & $\mathbf{3}$ & $\mathbf{4}$ & $\mathbf{5}$ \\
\hline July 2000 & 28.56 & 29.49 & 28.29 & 27.12 & 26.77 \\
August & 38.90 & 39.94 & 40.32 & 42.46 & 41.88 \\
September & 51.45 & 52.90 & 55.53 & 56.57 & 58.12 \\
October & 59.04 & 63.34 & 67.19 & 70.19 & 78.70 \\
November & 68.98 & 77.47 & 80.98 & 88.42 & 93.86 \\
\hline Growth rate & 0.63 & 0.75 & 0.74 & 0.82 & 0.86 \\
\hline
\end{tabular}

* Each group contains 80 fishes.

Table (4): Growth performance of Oreochromis niloticus fed the experimental diets.

\begin{tabular}{|c|c|c|c|c|c|}
\hline \multirow{2}{*}{ Growth Parameter } & \multicolumn{5}{|c|}{ Partitions } \\
\hline & 1 & 2 & 3 & 4 & 5 \\
\hline No, of fisl: per (g) & 28.56 & 29.49 & 28.29 & 27.12 & 26.77 \\
\hline Final weight $(\mathrm{g})$ & $68.98^{\mathrm{c}}$ & $77.47^{\mathrm{b}}$ & $80.98^{b}$ & $88.42^{h}$ & $93.86^{\mathrm{a}}$ \\
\hline Initial length $(\mathrm{cm})$ & 11.84 & 12.07 & 11.77 & 11.71 & 11.60 \\
\hline Final length $(\mathrm{cm})$ & 15.57 & 16.28 & 16.64 & 17.28 & 17.41 \\
\hline Initial condition factor & 1.72 & 1.68 & 1.74 & 1.69 & 1.71 \\
\hline Final condition factor & 1.77 & 1.80 & 1.76 & 1.71 & 1.78 \\
\hline Weight gain (g/fish) & 40.42 & 47.98 & 52.69 & 61.30 & 67.09 \\
\hline Weight gain $(\%)$ & 141.5 & 162.7 & 185.5 & 226 & 250.6 \\
\hline Average daily gain, (g/f/day) & 0.31 & 0.37 & 0.40 & 0.47 & 0.52 \\
\hline Specific growth rate $\%$ & 0.67 & 0.74 & 0.81 & 0.91 & 0.96 \\
\hline
\end{tabular}

$a, b$ and $c$ means in same raw with different superscripts are different $(P<0.05)$

Table (5): Economic evaluation of the experimental diets.

\begin{tabular}{|l|l|l|l|l|l|}
\hline \multicolumn{1}{|c|}{ Item } & \multicolumn{4}{c|}{ Partitions } \\
\cline { 2 - 6 } & \multicolumn{1}{c|}{$\mathbf{1}$} & \multicolumn{1}{c|}{$\mathbf{2}$} & \multicolumn{1}{c|}{$\mathbf{3}$} & \multicolumn{1}{|c|}{$\mathbf{5}$} & \multicolumn{5}{c|}{} \\
\hline Feed intake (Kg/partition) & 10.850 & 11.340 & 11710 & 12.070 & 12.730 \\
Feed cost (L.E./partition) & 7.76 & 8.45 & 10.78 & 9.66 & 11.62 \\
Final weight (kg/partition) & 5.518 & 6.198 & 6.478 & 7.074 & 7.509 \\
Weight gain (kg/partition) & 3.234 & 3.838 & 4.216 & 4.904 & 5.368 \\
Cost of producing one kg fish (L.E.) & 2.09 & 2.20 & 2.56 & 1.97 & 2.165 \\
Feed converssion ratio & 3.35 & 2.95 & 2.78 & 2.46 & 2.37 \\
\hline
\end{tabular}




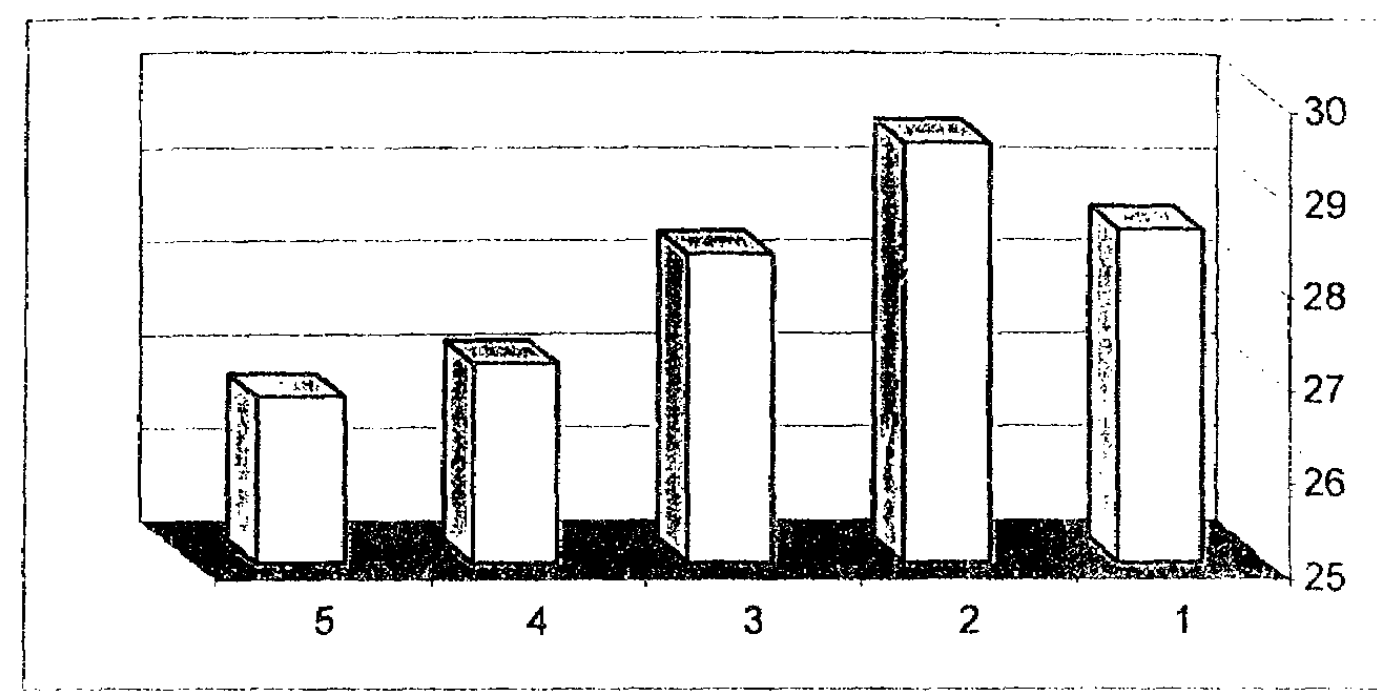

Fig. (1): Initial weight of $O$. niloticus in the diferent group.

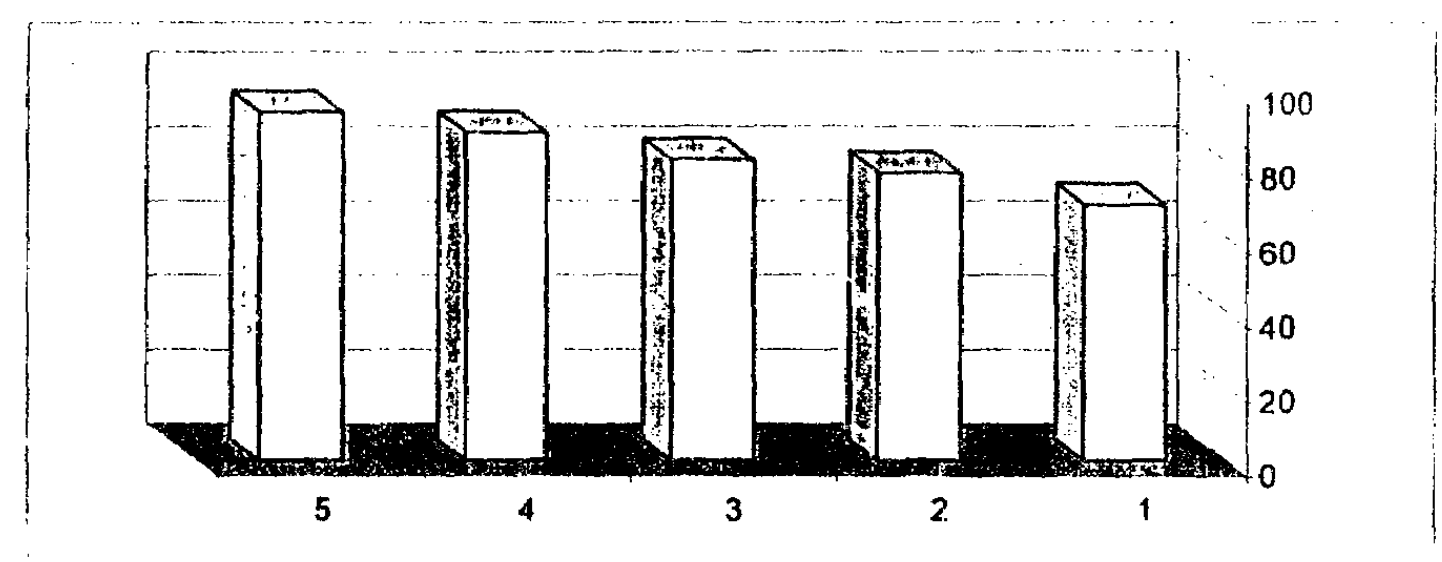

Fig. (2): Final weight of O. niloticus fed diferent diets.

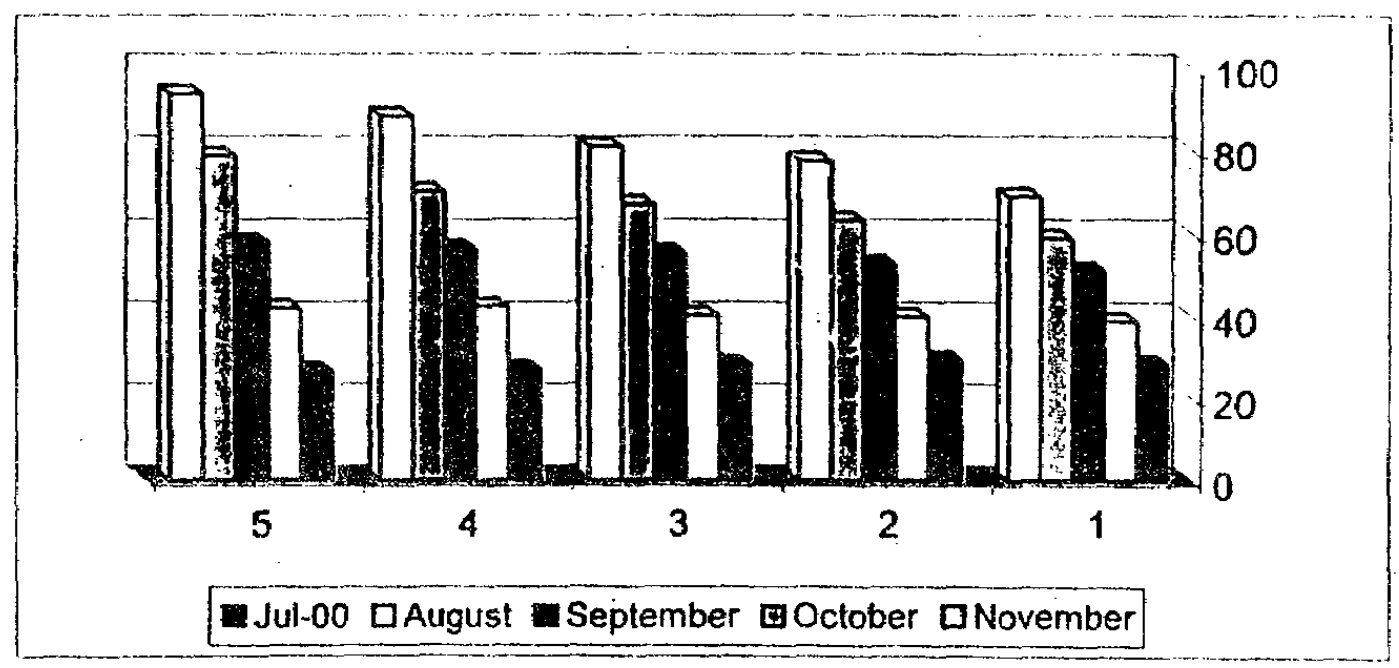

Fig. (3): Monthly body weight of $O$. niloticus fed different diets. 